EGU2020-20084

https://doi.org/10.5194/egusphere-egu2020-20084

EGU General Assembly 2020

(c) Author(s) 2020. This work is distributed under

the Creative Commons Attribution 4.0 License.

\title{
Flood risk assessment and cultural heritage impact in the Instituto Superior de Arte (ISA) in Habana.
}

\author{
Daniele Fabrizio Bignami ${ }^{1}$, Leonardo Stucchi ${ }^{2}$, Daniele Bocchiola ${ }^{2}$, Christian Zecchin ${ }^{2}$, Davide Del \\ Curto $^{2}$, Andrea Garzulino ${ }^{2}$, and Renzo Rosso ${ }^{2}$ \\ ${ }^{1}$ Fondazione Politecnico di Milano, Project Development Department, Milano, Italy (daniele.bignami@fondazione.polimi.it) \\ ${ }^{2}$ Politecnico di Milano
}

Keeping ISA Modern is a project of Fondazione Politecnico di Milano and other partners aimed at planning the conservation of some of the buildings (Schools) of the University of Arts (ISA) of Cuba, built over a former country club, designed by eminent architects of the time (Vittorio Garatti, Roberto Gottardi and Ricardo Porro), and bestowed with the status of UNESCO World Heritage in 2003.

Most of the Schools are currently unusable, also due to damages caused by frequent floods from the surrounding Rio Quibù river, and they need urgent restoration if they are to be used. Personnel of Politecnico di Milano carried out a field survey on the Rio Quibù during 2019, and also based upon information from the Cuban National Institute of Hydraulic Resources (INRH) they studied established flood risk for ISA.

Here, we built a high-resolution digital terrain model (DTM) of the park where Schools are located, using laser scanner data, and previously georeferenced points. Using field measurements taken in June 2019 we were able to assess geometry (included bridges), slope and roughness coefficients of the main channel of the Quibù river, influence of the sea level. Then using as input critical discharge data provided by INRH we evaluated flood area and flood volume for 4 representative return periods $(5,20,50,100$ years).

The most impacted building is the School of Ballet, located within a narrow meander of Rio Quibù, immediately upstream of a narrow bridge, clogging largely during floods, only $1 \mathrm{~km}$ far from the sea, and with drainage system unable to discharge storm water.

Given the high required cost, a partially collapsed wall originally partially protecting the School of Ballet was not rebuilt, and we are now exploring flood mitigation strategy which are cheaper, and feasible from the point of view of compatibility with the historical and architectural value of the building. 